\title{
how to make love to a chicken
}

\author{
Sylvia Legris
}

\section{Comment faire l'amour à un poulet}

Dans ce poème, les souvenirs d'une mère préparant un poulet paprikash rejoignent ceux d'une enfance abusée. Les préparatifs de la cuisson des poitrines de poulet ( le choix de la viande au marché, le plumage, la coupe appropriée) servent de catalyseur contre les effets del'abus paternel envers son corps. "Combien de synonymes existe-t-il pour «mutilation»?" demande la narratricequi ne peut pas verbaliser sa colère. Elle ne peut que nous prévenir du danger que peut représenter un poulet à la peau violace, meurtrie et fendue. 


\section{A. peel back skin}

her mother makes chicken paprikash

uses finest ingredients

tomatoes fresh never canned

blanches them in twos

unwraps like paper

uses free-range chicken from the st john boys

they sell them in fort rouge door to door

tells her daughter: these are the choicest birds in winnipeg

with chickens like these....

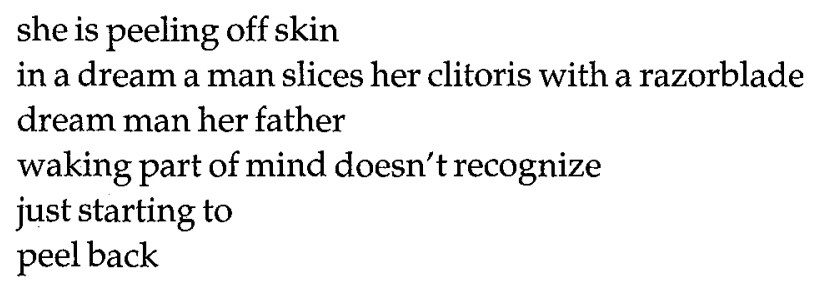

her mother shows how to disjoint chicken

this cleaver sharp you must be careful 


\section{B. insert point of steel}

how many synonyms for mutilation she cannot count fingers

in a dream her father cuts her tongue tells police she slipped in bathtub only four but knows a lie when she hears one

how many synonyms for mutilation?

she cannot speak

\section{C. always save the wishbone}

to size up a chicken

look for moist skin

soft legs, feet

bright eyes and

most importantly

a flexible breast bone

put the bird on its side

separate breast from back

CHOP exactly

through middle of ribs

CHOP front from spine more than one blow CHOP 


\author{
go for the glasses \\ without them she's defenseless
}

\author{
BREAST DOWN: dislocate legs \\ (just breathe breathe \\ BREAST UP: work flesh \\ from bone \\ in breathe out breathe \\ BREAST DOWN: loosen flesh \\ sharp knife \\ justbreathe justbreathe)
}

to size up a chicken

beware if skin is:

purplish

bruised

slit 